\title{
The Impact of Macroeconomic Variables on Gross Domestic Product: Empirical Evidence from Ghana
}

\author{
Evans Agalega ${ }^{1} \&$ Samuel Antwi ${ }^{1,2}$ \\ ${ }^{1}$ Accountancy Department, Koforidua Polytechnic, Koforidua, Ghana \\ ${ }^{2}$ School of Finance and Economics, Jiangsu University, Jiangsu, Peoples Republic of China \\ Correspondence: Samuel Antwi, School of Finance and Economics, Jiangsu University, 301 Xuefu Road, \\ Zhenjiang, Jiangsu, Peoples Republic of China. Tel: 86-189-1282-3943. E-mail: samyantwi@yahoo.com
}

\author{
Received: February 17, $2013 \quad$ Accepted: March 16, $2013 \quad$ Online Published: April 17, 2013 \\ doi:10.5539/ibr.v6n5p108 URL: http://dx.doi.org/10.5539/ibr.v6n5p108
}

\begin{abstract}
Macroeconomic variables such as interest rates, inflation and exchange rates play a vital role in the economic performance of any country. The main objective of this paper was to investigate the effect that changes in the inflation and interest rates have on the Gross Domestic Product (GDP) in Ghana over a period of thirty one (31) years from 1980-2010. Data were collected from Bank of Ghana publications and bulletins, Ghana Statistical Service, the Institute of Statistical, Social and Economic Research (ISSER). The paper employed multiple linear regressions to establish that there exists a fairly strong positive correlation between GDP, Interest rate and Inflation, but Inflation and Interest rate could only explain movement in GDP by only 44 percent. The paper further established that, there existed positive relationship between inflation and GDP and interest rate is negative. It is recommended among others that the Government together with the Bank of Ghana should develop and pursue prudent monetary policies that would aim at reducing and stabilizing both the micro and macroeconomic indicators such as inflation targeting, interest rate, so as to boast the growth of the economy.
\end{abstract}

Keywords: Ghana, inflation, interest rate, Gross Domestic Product, regression analysis

\section{Introduction}

For all countries, both developed and developing, one of the fundamental objectives of macroeconomic policy is economic stability. In Ghana, monetary and fiscal policies are aimed at sustaining high growth rates in terms of Gross Domestic Product (GDP) together with low inflation by way of price stability. Ghana has been targeting a single digit average inflation rate. The monetary policy committee (MPC) of Bank of Ghana on $15^{\text {th }}$ may, 2011 reduced it policy rate from $13.5 \%$ to $13 \%$ as a result of improvement in the economy. This was expected to trigger a reduction in the interest rate of the commercial banks and consequently make the cost of borrowing cheaper. Boyd et al. (2001) examines five -year average data on bank credit extension to the private sector, the volume of bank liabilities outstanding, stock market capitalization and trading volume (all as ratios to GDP) and inflation for a cross section sample over 1960-1995, Boyd et al. (2001) finds that, at low to moderate rates of inflation, increases in the rate of inflation lead to markedly lower volumes of bank lending to the private sector, lower levels of bank liabilities outstanding and significantly reduced levels of stock market capitalization and trading volume. According to Frimpong and Oteng 2010, a high rate of inflation beyond 14\% will always hurt GDP, the reason for Bank of Ghana monetary planning committee always targeting a single digit rate. Macroeconomic variables such as inflation, interest rate, exchange rate etc. have been established by considerable research to be of great determinants of GDP elsewhere in developed countries. Successive governments in Ghana had initiated several fiscal and monetary policies aimed at bringing inflation and interest rate down with the view to boosting economic growth as measured by GDP. Whiles these policies might be good, the effects of these macroeconomic variables on the economies of developing countries has not been well established. Literature on these variables is sparsely available and scattered. We are not sure of the exact correlation between some of these variables especially inflation and policy rate and GDP. To what extent should the government pursue its objective of single digit inflationary target? Are inflation and Policy rate determinants of GDP in Ghana? These and many more are the macroeconomic problems that ought to be answered in Ghana. The general objective of the study was to investigate the effect of changes in the inflation and policy rates on the Gross Domestic Product (GDP) of Ghana over the period. 


\subsection{Relationship between Inflation and GDP}

Lupu D. V. (2007) established that there is a positive relationship between inflation and GDP growth in Romania in the short run. This implies that, as inflation increases GDP must also increase in the short run. However, when inflation decreases, GDP should also decrease. Drukker et al (2005) established that, if inflation rate is below $19.16 \%$, increases in inflation do not have a statistically significant effect on growth, but, when inflation is above $19.16 \%$; further increases in inflation will decrease long run growth. This affirmation is in line with Lupu D. V. (2007) but only that, it establishes a threshold beyond which the assertion of Lupu D. V. (2007) will not hold. Mallik et al (2001) established a long run positive relationship between GDP growth rate and Inflation among four South Asian Countries. However, Kasim et al (2009) was able to establish the non-linearity between inflation rate and GDP growth rate in Malaysia. His study analysed the relationship between inflation rate and economic growth rate in the period 1970-2005 in Malaysia. A specific question that is addressed in this study is what the threshold inflation rate for Malaysia. The findings suggest that there is one inflation threshold value exist for Malaysia. This evidence strongly supports the view that the relationship between inflation rate and economic growth is nonlinear. The estimated threshold regression model suggests $3.89 \%$ as the threshold value of inflation rate above which inflation significantly retards growth rate of GDP.

\subsection{The Relationship between Interest Rate and GDP}

Obamuyi T.M. (2006) established that lending rates have significant effects on GDP; this implies that there exists a unique long run relationship between GDP growth and interest rates and that the relationship is negative. This means when interest rate reduces, GDP in the short run will increase, but when interest rate declines GDP will increase.

\section{Methodology}

\subsection{Source and Data Collection Procedure}

Since the source of the data collected was secondary, the procedure for the data collection was relatively simple. More specifically, data were collected from available records, publications and bulleting of the Bank of Ghana, the Ghana Statistical Service, the Institute of Statistical Social and Economic Research (ISSER) -Ghana, and also from the internet (from www.indexmundi). These data were then taken to the regional office of the Ghana Statistical Service (GSS) Ashanti Region -Kumasi for authentication. The data collected with regard to GDP, interest rate and inflation rate covered the period 1980 to 2010 which gives thirty one (31) data points which is statistically large to be used for the study.

\subsection{Model Specification}

The model used in this study is multiple linear regression models. This attempted to look at the effects or the relationship between a dependent (responsible) variable and number independent (explanatory) variables.

With regard to this study, the dependent variable is Gross Domestic Product (GDP) and the independent or explanatory variables are inflation and interest rates.

The model specified is therefore:

$\mathrm{Y}=\beta_{0}+\beta_{1 \mathrm{X} 1}+\beta_{2 \mathrm{X} 2}+\varepsilon_{i j}$. Letting GDP $=\mathrm{Y}$, Inflation $=\mathrm{X}_{1}$, and Interest rate $=\mathrm{X}_{2}$. The model is re-specified as GDP $=\beta_{0}+\beta_{1}$ Inflation rate $+\beta_{2}$ Interest rate, where $\beta_{0}, \beta_{1}$ and $\beta_{2}$ are the regression coefficients which are estimated from the sample data. The $\varepsilon_{i j}$ is the random error term.

\subsection{Method of Data Analysis}

All information (data) collected from the secondary source were sorted out, edited and collated with the aid of simple tables to enabled the overall perspective of the data to be determined quickly and easily as well as enabling interpretations and meaningful conclusions to be drawn. Furthermore, in order to substantiate the effectiveness of the information presented in the tables, line graphs have been used to display the data.

Statistical computer software programme was used to conduct the inferential statistical analysis. Specifically the Statistical Package for the Social Scientist (SPSS) has been used to analyze such data.

\subsection{Model Adequacy Checking}

This is done first by testing for individual regression coefficients. The dependence of $\mathrm{Y}$ and $\mathrm{X}_{\mathrm{j}}$ can be assessed by testing the significance of $\beta_{\mathrm{j}}$. The hypothesis is

$\mathrm{H}_{0}: \beta_{\mathrm{j}}=0$ and 
$\mathrm{H}_{1}: \beta_{\mathrm{j}} \neq 0$.

The test statistics is:

$\mathrm{t}=\frac{\beta j}{S(\beta j)}$ where, $\mathrm{S}\left(\beta_{\mathrm{j}}\right)=\frac{s}{\sqrt{\sum_{i=1}^{n}}(x i-x) 2}$ the test statistics has the student's $\mathrm{t}$-distribution in with n-k-1 degrees of freedom.

Secondly, tests for a set of regression coefficients are also carried out. Here the hypothesis is

$\mathrm{H}_{0}: \mathrm{B}_{\mathrm{y}+1}=\mathrm{B}_{\mathrm{y}+2}=\ldots . .=\mathrm{B}_{\mathrm{k}}=0$

$\mathrm{H}_{1}$ : at least one of the $\mathrm{Bs}$ is not equal to 0

The test statistics is $\mathrm{F}$ which is derived with the help of the ANOVA Table from the output.

Finally, graphical display of the residual is further examined. A histogram plot of the residuals must look like a sample drawn from a normal distribution centered at 0 .

Also, a probability plot of the residuals must resemble a straight line. Again, a plot of residuals in the sequence must show no pattern or be structuralless as well as plot of residuals against fitted values.

\section{Empirical Results and Discussions}

\subsection{Model Formulation}

The linear regression model is developed as follows using the output results (coefficients) displayed in Table 1.

Table 1. Regression coefficients

\begin{tabular}{lllll}
\hline \multirow{2}{*}{ Model } & \multicolumn{2}{l}{ Unstandardized Coefficients } & \multicolumn{2}{c}{ Sig. } \\
\cline { 2 - 4 } & $\mathrm{B}$ & \multicolumn{2}{c}{ Std. Error } & \\
\hline (Constant) & 14.988 & 1.945 & 7.706 & .000 \\
Inflation $\left(\mathrm{X}_{1}\right)$ & .055 & .024 & 2.285 & .030 \\
Interest $\left(\mathrm{X}_{2}\right)$ & -.305 & .072 & -4.244 & .000 \\
\hline
\end{tabular}

From Table 1 above, the exact regression model that can be developed is thus $\mathrm{Y}=14.988+0.055 \mathrm{X}_{1}-0.305 \mathrm{X}_{2}$, where $\mathrm{Y}, \mathrm{X}_{1}$ and $\mathrm{X}_{2}$ denote their usual meanings. The model is thus interpreted as follows:

The constant value of 14.988 is the intercept which represent total output of the Ghanaian economy in terms of its Gross Domestic Product (GDP) given that inflation rate $\left(\mathrm{x}_{1}\right)$ and interest rate $\left(\mathrm{x}_{2}\right)$ are zero, all other factors held constant. On the other hand the coefficients of $\mathrm{x}_{1}$ (i.e. inflation rate) of 0.055 implies how much or the magnitude by which GDP would change (in this case would increase) per unit change in $\mathrm{x}_{1}$ (inflation rate). This of course shows that there is a positive relationship between GDP and inflation rate given the data for the period under consideration. This means that both GDP and inflation rate behave or move in the same direction. As inflation rate increases GDP also increase. Inflation and GDP move together because, during the period of inflation, especially the demand pull inflation, could lead to increase in demand for goods and services, this could lead to increase in productivity and for that matter increasing the GDP consequently. During the period of mild inflation or decrease in inflation, it could lead to decrease in demand for most goods and services and for that matter, a decrease in productivity of factors of production and consequently decrease in Gross Domestic Product (GDP). Also, the coefficient of $x_{2}$ (i.e. - 0.305 ) imply how much GDP would change (would decrease) by if there is a unit increase in the interest rate. It further indicates a negative or inverse relationship between GDP and interest rate. This means that interest rate and GDP move in opposite directions. That is as interest rate also decreases GDP increases and vice versa. Also, this relationship is supported by literature as reviewed above that if inflation is rising the central bank raises the interest rate, meaning that the cost of borrowing increases so the amount of money borrowed by individuals and companies decreases which in turn decreases the amount of money in the economy (money supply) resulting in low economic output and for that matter GDP. The above arguments are corroborated by the line diagram below using the data for Inflation, Policy Rate and GDP from 1980 to 2010 for the Ghanaian economy as used in the study. 


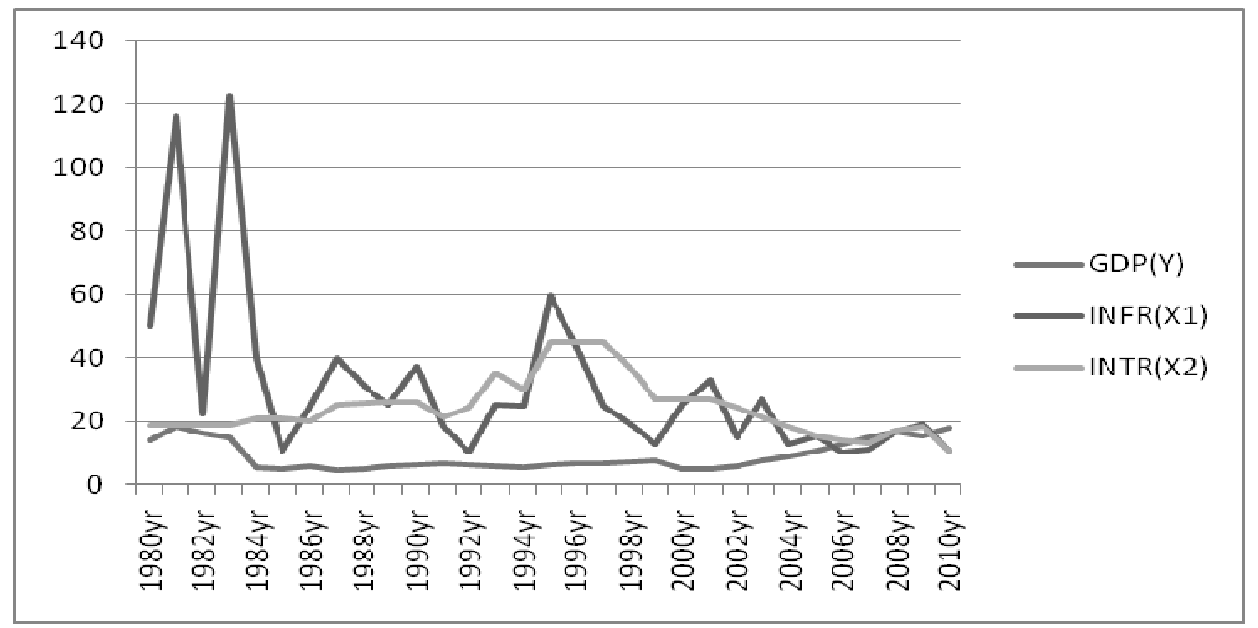

Figure 1. Line graphs of GDP, inflation and policy rates from 1980 to 2010

Figure 1 shows the performance of the Ghanaian economy in terms of the GDP, with regard to inflation rates and interest rates from the year 1980,1981, 1982, through to 2010. The graph shows that the performance of the Ghanaian economy in terms of GDP, with regard to inflation rates and interest rates have not remained constant over the period, but rather have been growing steadily with moderate fluctuations especially during the periods of 1983, 1984 and 2000. As can be seen in Figure 1, some years recorded high figures whilst others recorded very low figures. For instance inflation rates were high during the periods of 1980, 1981 and 1983. This could be attributed to drought and wide scale bush and forest fires that engulfed the country around the period and thus created severe nation-wide famine especially in 1983.

Table 2. Model summary of other regression coefficients

\begin{tabular}{llllll}
\hline Model & R & R2 & Adjusted R Square & Std. Error of the Estimate & Durbin-Watson \\
\hline 1 & 0.660 & 0.435 & 0.395 & 3.497 & 0.406 \\
\hline
\end{tabular}

The multiple linear regression model developed in Table 2 can confidently be used after having been satisfied with the assumptions if it is found to be adequate. The model adequacy checking is done using the statistics in Table 2. The $\mathrm{R}$ and $\mathrm{R}^{2}$ represent the multiple correlation and coefficient of determination respectively. The $\mathrm{R}$ (0.66) shows that there exist a strong positive relationship between GDP as the dependent variable and interest and inflation rates as the independent variables. This therefore also implies that the behavioral patterns of interest and inflation rates did influence Ghana's GDP. As inflation rises, GDP increases and so on. This is corroborated by the coefficient of inflation rate in the regression model developed above in table 2. Also, this relationship is supported by literature as reviewed above that if inflation is rising the central bank raises the interest rate, meaning that the cost of borrowing increases so the amount of money borrowed by individuals and companies decreases which in turn decreases the amount of money in the economy (money supply) resulting in low economic output and for that matter GDP. Furthermore, Mundell tackled the old Fisherian law on the constancy of the real rate of interest, i.e. where $r=i-\pi$ where if inflation $(\pi)$ rises, then nominal interest rate (i) will rise one-for-one to keep real interest rates (r) constant. However, Keynes (1936) disputed Fisher's assertion and Fisher (1930), was reluctant to make too much out of it empirically. Mundell's reasoning was as follows: the nominal rate of interest is set by inflation expectations and the real interest rate, $i=r+\pi^{e}$. Now, suppose we have two assets, money and equity, where $r$ is the real return on equity. By Keynes's theory of liquidity preference, money demand is inversely related to the return on alternative assets, i.e. L(r, Y). We know, of course, that in equilibrium $\mathrm{M} / \mathrm{p}=\mathrm{L}(\mathrm{r}, \mathrm{Y})$, as money supply rises, the rate of interest falls, so we can trace out an money market (MM) equilibrium locus in interest/money supply space as in the Figure below. Now, a particular MM curve is conditional on a particular level of inflationary expectations $\left(\pi^{\mathrm{e}}\right)$. If inflationary expectations rise, then, for any given amount of money supply, the real interest rate, $r=i-\pi^{\mathrm{e}}$, falls and thus the MM curve shifts down. The intuitive logic is that we must remember that the negative of inflation is the real rate of return on money. Thus, if there are inflationary expectations, agents who hold money are receiving a negative expected return on their real balances and thus will attempt to get rid of them by purchasing equity. As a result, money demands falls and the price of equity rises - and consequently the real rate of return on equity, $r$, and falls. On the 
contrary, the relationship between interest rate and GDP is such that they move in opposite directions. As interest rate increases, GDP decreases and vice versa. This relationship is corroborated by the negative coefficient of interest rate in the regression model developed in 3. This relationship is also supported by the literature reviewed above. As GDP increases, interest rates (policy) rate falls. This is because a sustained increase in Gross domestic product (GDP) is having a tendency of lowering inflationary rate, and would lead to a decrease in the policy rate; this is consistent to the monetary policy committee (MPC) of the bank of Ghana (BOG), the committee, reduced the policy rate from $13.5 \%$ to $13 \%$ as a result of a reduction risks of inflationary rate increase and improvement in economic growth. Furthermore, the $\mathrm{R}^{2}$ (coefficient of determination) value of 0.435 or $44 \%$ means that approximately $44 \%$ of the proportion of variations in GDP are explained by both inflation and interest rates. It can simply be put as inflation and interest rates accounted for $44 \%$ of the changes in GDP with regard to the data for the period under review. Moreover, the adjusted $\mathrm{R}^{2}$ (coefficient of determination adjusted for the degrees of freedom) value of 0.395 (approximately $40 \%$ ) is in line with the $\mathrm{R}^{2}$ value already explained above. This also implies that interest and inflation rates account for $40 \%$ of the changes in GDP.

Table 3. Analysis of variance (ANOVA)

\begin{tabular}{llllll}
\hline Model & Sum of Squares & Df & Mean Square & F & Sig. \\
\hline Regression & 264.001 & 2 & 132.001 & 10.792 & .000 \\
Residual & 342.480 & 28 & 12.231 & & \\
Total & 606.481 & 30 & & & \\
\hline
\end{tabular}

Notes: a. Predictors: (Constant), Inflation(X2), Interest(X1). b. Dependent Variable: GDPY.

The analysis of variance (ANOVA) table above is used to test the overall significance of the model developed and for that matter whether the beta coefficient are the same or not.

The hypothesis that is tested here is:

Null hypothesis $\left(\mathrm{H}_{0}\right)$ : The overall model is not significant, i.e. $\mathrm{H}_{0}: \beta_{\mathrm{j}}=0$

Alternative hypothesis $\left(\mathrm{H}_{1}\right)$ : The overall model is significant, i.e. $\mathrm{H}_{1}: \beta_{\mathrm{j}} \neq 0$

The level of significance selected is $\alpha=0.05$. The decision rule is do not reject the null hypothesis if the $F$ calculated is less than the F critical, or if the significant value is less than the level of significance $(\alpha=0.05)$. The decision and conclusion, is that since the significant value of 0.000 is less than 0.05 , therefore the null hypothesis is rejected. Thus it can be concluded that at least one beta coefficient is not zero and for that matter the overall model is significant. Finally, the significant values recorded in the last column of Table 3 also indicate that all the individual beta coefficients are significant.

\subsection{Relationship between GDP and Inflation}

In addition to the relation developed for GDP, in terms of inflation rate and interest rate, the relationship between GDP and inflation rate is also examined as follows.

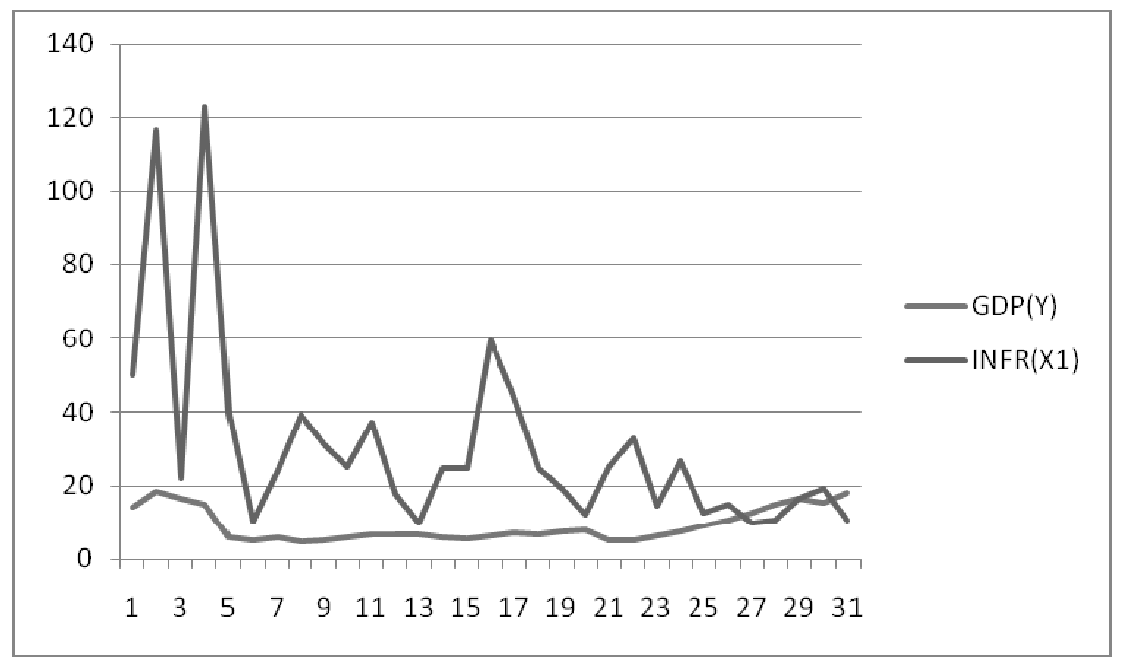

Figure 2. Line graph of GDP and Inflation rate from 1980 to 2010 
The pattern of trend of GDP and inflation rate obtained in the figure 2 above is not different from that obtained in figure 1 above over the thirty-one (31) year period under study. It shows clearly that the GDP for the Ghanaian economy has grown steadily over the years under study with a few moderate declines between 1983 up to 1985 with corresponding high increases in inflationary rates. The figure further shows that there has been serious fluctuations in the inflationary rates with only moderate movements in 2007 up to 2010. These movements in the line graphs shows that there has been a relationship between GDP and inflation rates over the period under study. Where inflationary rates were high, GDP was low or modereate and vice versa.

Table 4. Regression statistics of GDP and inflation

\begin{tabular}{ll}
\hline Multiple R & 0.248476 \\
R Square & 0.0617403 \\
Adjusted R Square & 0.0282311 \\
Standard Error & 4.4134103 \\
\hline Observations & 31 \\
\hline
\end{tabular}

With regard to the nature of the relationship between GDP as a dependent variable and inflation as the independent or explanatory variable, it can be said based on the correlation coefficient $(\mathrm{R}=0.248476)$ that there exists a weak positive relationship between GDP and inflation. Also based on the coefficient of determination value ( $\mathrm{R}$ square $=0.0617403$ ) it can be concluded that inflation could explain or account only approximately $6 \%$ of the changes in GDP over the period. This therefore implies that there about $94 \%$ of the changes in GDP that rather accounted for by other macroeconomic variables.

Table 5. Regression coefficients

\begin{tabular}{lllll}
\hline & Coefficients & Standard Error & t Stat & P-value \\
\hline Intercept & 7.7978165 & 1.216943561 & 6.407706 & $6.2 \mathrm{E} 07$ \\
Inflation rate & 0.0411398 & 0.030308217 & 1.357382 & 0.1855 \\
\hline
\end{tabular}

Based on the regression coefficients in Table 5 above, a simple linear regression equation that can be modeled is $\mathrm{Y}=7.7978+0.04114 \mathrm{X}$, where $\mathrm{Y}$ is the dependent variable that is GDP and $\mathrm{X}$ being the independent variable representing inflation. This relationship shows that GDP will increase with a corresponding increase in inflation. However, this increment may not be significant since the P-value for the coefficient is not significant. This could better be improved if additional variables are added to the model. For instance in the model developed for GDP as the dependent variable using inflation and interest rates as the explanatory variables, the constant term is 14.988 which is about twice of that obtained for this model.

Table 6. Analysis of variance

\begin{tabular}{llllll}
\hline Source variation & Df & SS & MS & $F$ & Significance $F$ \\
\hline Regression & 1 & 35.88827652 & 35.88828 & 1.84249 & 0.18550085 \\
Residual & 28 & 545.3893298 & 19.47819 & & \\
Total & 29 & 581.2776063 & & & \\
\hline
\end{tabular}

The analysis of variance is at this juncture used to test the overall significance of the linear regression equation developed between GDP and inflation. It can be seen from the sum of squares values that the residual sum of squares of 545.3893298 is far bigger than the regression sum of squares of 35.88827652 . This goes a long way to affect the reliability of the model. The decision rule is do not reject the null hypothesis if the F calculated is less than the F critical, or if the significant value is less than the level of significance $(\alpha=0.05)$. The decision and conclusion, is that since the significant value of 0.18550085 is greater than 0.05 , therefore the null hypothesis is not rejected. This thus confirms the high sum of squares residual value of 545.3893298 out of a total of 581.2776063. Therefore, it can be concluded that the model developed for GDP in terms of inflation is not significant. 


\subsection{The Regression Statistics between GDP and Policy Rate (Interest Rate)}

Table 7. Regression statistics of GDP and policy rate in Ghana from 1980 to 2010

\begin{tabular}{ll}
\hline Regression Statistics & \\
\hline Multiple R & 0.566729794 \\
R Square & 0.321182659 \\
Adjusted R Square & 0.296939183 \\
Standard Error & 3.753956575 \\
Observations & 31 \\
\hline
\end{tabular}

With regard to the nature of the relationship between GDP as a dependent variable and policy rate as the independent or explanatory variable, it can be said based on the correlation coefficient $(\mathrm{R}=0.566729794)$ that there exists a moderate positive relationship between GDP and policy rate. Also based on the coefficient of determination value ( $\mathrm{R}$ square $=0.321182659$ ) it can be concluded that policy rate is able to explain or account for only approximately $32 \%$ of the changes in GDP over the period. This therefore implies that there about $68 \%$ of the changes in GDP that rather accounted for by other macroeconomic variables.

Table 8. Regression coefficients

\begin{tabular}{lllll}
\hline & Coefficients & Standard Error & $t$ Stat & $P$-value \\
\hline Intercept & 15.97346453 & 2.025556189 & 7.885965 & $1.37 \mathrm{E}-08$ \\
Interest rate & -0.281298738 & 0.077283928 & -3.63981 & 0.001094 \\
\hline
\end{tabular}

Based on the regression coefficients in Table 8 above, a simple linear regression equation that can be modeled is $\mathrm{Y}=15.97346453+(-0.281298738) \mathrm{X}$, where $\mathrm{Y}$ is the dependent variable that is GDP and $\mathrm{X}$ being the independent variable representing policy rate. This relationship shows that GDP increases with a corresponding decrease in policy rate. This increment is also significant since the P-value for the coefficients are significant. The reliability of the model is tested below using the analysis of variance table below.

Table 9. Analysis of Variance

\begin{tabular}{llllll}
\hline & $D f$ & $S S$ & $M S$ & $F$ & Significance $F$ \\
\hline Regression & 1 & 186.6962872 & 186.6963 & 13.24821 & 0.001093836 \\
Residual & 29 & 394.5813191 & 14.09219 & & \\
Total & 30 & 581.2776063 & & & \\
\hline
\end{tabular}

The importance of the reliability of the model developed above for the relation between GDP and policy rate cannot be over ruled, since it would go a long way in informing its usage in estimation and forecasting. Since the calculated F of 13.24821 is far greater than the F significance, the null hypothesis is not rejected. It therefore can be concluded that the model developed for GDP in relation to policy rate for Ghana using the data covering these two variables from 1980 to 2010 is quite significant.

\section{Conclusion}

It can be concluded from the findings that there exist a strong positive correlation (relationship) of 0.66 between GDP, interest rate and inflation rates over the period under study. This therefore also implies that the behavioral patterns of interest and inflation rates have had some influence on GDP. Furthermore, the study revealed an $\mathrm{R}^{2}$ value of $0.435(44 \%)$; this implies that an approximately $44 \%$ of the proportion of variations in GDP are explained by both inflation and interest rates. It can simply be put as inflation and interest rates accounted for or explained only $44 \%$ of the changes in the GDP of Ghana with regard to the data for the period 1980 to 2010 . Therefore there are about $56 \%$ of the changes in the GDP of the Ghanaian economy that could not be explained by inflation and interest rates that need to be investigated. It can also be concluded from the findings that indeed there exist some relationship between GDP, inflation and interest rates as already established and this is given by the linear multiple regression model: $\mathrm{Y}=14.988+0.055_{\mathrm{X} 1}-0.305_{\mathrm{X} 2}$, where $\mathrm{Y}$ is the GDP; $\mathrm{X}_{1}$ is the inflation rate; and $X_{2}$ is the interest rates over the period 1980 through to 2010.

Furthermore, it was revealed that there is a positive relationship between GDP and inflation rate given the data for the period under consideration and it therefore means that both GDP and inflation rate behaved or moved in the same direction. As inflation rate increased GDP also increased and vice versa. However, it indicated a 
negative or inverse relationship between GDP and interest rate. This means that interest rate and GDP move in opposite direction. That is as interest rate increases, GDP decreases and vice versa. Also, the test of hypothesis with the analysis of variance table have revealed that overall multiple regression model developed for GDP, interest rate and inflation rate was significant with the individual parameter estimates also being significant. Therefore given any projected interest and inflation rates for a given period, the projected corresponding GDP can be estimated but with a precision of only $40 \%$ or $44 \%$. Finally, it can be concluded based on the individual examination of the relationship between GDP, inflation and policy rate that there exists some relationship between GDP and inflation rate as well as GDP and policy rate. It is recommended that the Government together with the Bank of Ghana should develop and pursue prudent monetary policies that would aim at reducing and stabilizing both the micro and macroeconomic indicators such as inflation targeting, interest rate, so as to boast the growth of the economy.

\section{References}

Adenutsi, D. E. (2008). Effect of Trade openness and Foreign Direct Investment on Industry Performance in Ghana. Journal of Business Research, 2, 1-2.

Allen, L. (1998). The Determinants of Bank of Ghana Interest. Journal of Financial and Quantitative Analysis, 23(2), 231-235. http://dx.doi.org/10.2307/2330883

Antwi Samuel, E. F. E., Mills, A., \& Zhao, X. (2013). The impact of macroeconomic factors on economic growth in Ghana. A cointegration Analysis. International Journal of Academic Research in Accounting, Finance and Management Science, 3(1), 35-45.

Arnold, A. R. (2005). Macroeconomics (7th ed.). Ohio, South-Western.

Asogwa, R. (2006). Global Financial Regulatory Harmonization, Central Banks' Supervisory Effectiveness and Macroeconomic Performance in the West African Monetary Zone (WAMZ) Countries: Analyzing the Role of Institutional Factors. Paper presented at the 7th Global Development Network Annual Conference, St Petersburg, Russia, 19-21.

Bank of Ghana. (2009). Financial Stability Reports: Monetary Policy Committee Statistical Releases, 2002-2008.

Barro, R. J. (1991). Economic Growth in a Cross-Section of Countries. Quarterly Journal of Economics, 106, 407-444. http://dx.doi.org/10.2307/2937943

Barro, R. J. (2003). Determinants of Economic Growth in a Panel of Countries. Annals of Economics and Finance, 4, 231-274.

Bawumia, M. (2010). Monetary Policy and Financial Sector Reform in Africa: Ghana's Experience. Accra: Combert Impressions Ghana Ltd.

Beck, T., \& Laeven, L. (2005). Institution Building and Growth in Transition Economies. World Bank Policy Research Working Paper, 3657. Retrieved from htte://econpapers.repec.org/RePEc:wbk:wbrwps:3657

Carden, A. (2005). Inputs and Institutions as Conservative Elements. Draft paper. Retrieved from http://www.gmu.edu/rae/featured/archives/Carden_essay.pdf

Danquah, M. (2006). Sources of Growth in Ghana. Retrieved from http://unpan1.un.org/intradocgroups/public/document/IDEP/UNPAN023359pdf

Drukker, D., Hernandez-Verme, P., \& Gomis-Porgueras, P. (2005). Threshold Effects in the relationship between Inflation and Growth: A new Panel-Data Approach. Retrieved from http://ideas.repec.org/p/pra/mprapa/33494.html

Easterly, W., \& Levine, R. (1997). Africa's Growth Tragedy: Policies and Ethnic Divisions. Quarterly Journal of Economics, 112(4), 1203-50. http://dx.doi.org/10.1162/003355300555466

Fischer, S. (1993). The Role of Macroeconomic Factors in Growth. Journal of Monetary Economics, 32 , 485-512. http://dx.doi.org/10.1016/0304-3932(93)90027-D

Frimpong, J. M., \& Oteng-Abayie, E. F. (2008). Bivariate Causality Analysis between FDI Inflows and Economic Growth in Ghana. International Research Journal of Finance and Economics, 15.

Frimpong, J. M., \& Oteng-Abayie, E. F. (2010). When is Inflation Harmful? Estimating the Threshold Effect for Ghana. Am. J. Econ. Bus. Admin., 2, 232-239. http://dx.doi.org/10.3844/ajebasp.2010.232.239

International Monetary Fund. (2007). Ghana selected Issues: IMF country Report No 07/208. Retrieved from 
http://www.imf.org/external/pubs/ft/scr/2007/cr07208.pdf

Jar, C., \& Lawrence, B. S. (1970). The Fundamental Determinants of Interest Rates. Review of Economic and Statistics, 52, 363-375. http://dx.doi.org/10.2307/1926313

Kassim, M., \& Munir, Q. (2009). Non-Linearity between Inflation rate and GDP Growth in Malaysia. Economic Bulletin, 29(3), 1555-1569.

Levine, R. (1999). Financial Development and Growth: Where Do We Stand? Estudios de Economia, 26(2), 113-136.

Levine, R., \& Renelt, D. (1992). A Sensitivity Analysis of Cross-Growth Regression. American Economic Review, 82(4), 942-63.

Levine, R., \& Zervos, S. J. (1993). What have we learned about Policy and Growth from Cross Country Regression? American Economic Review, 83(2), 426-30.

Luppu, D. V. (2009). The Correlation between Inflation and Economic Growth in Romania. Luccrari Stiintifice Vol. 53, Seria Zootechnie.

Mallik, G., \& Chowdury, A. (2001). Inflation and Economic Growth: Evidence from Four South Asian Countriess. Asia-Pacific Development Journal, 8(1).

Mankiw, N. G. (2000). Macroeconomics (4th ed.). USA: Worth Publishers.

Mankiw, N. G., Romer, D., \& Weil, D. N. (1992). A contribution to the Emprise of Economic Growth. Quarterly Journal of Economics, 107.

Temple, J. (1999). The New Growth Evidence. Journal of Economic Literature, 37(1). http://dx.doi.org/10.1257/jel.37.1.112

Truman, E. M. (2008). Inflation Targeting in the World Economy, Institute for International Economics, Washington. Retrieved from http://www.economics-ejournal.org/economics/journalarticles/2008-31

William, P. (1972). Money Supply, Interest Rates and Yield Curve. Journal of Money, Credit and Banking, 4, 582-594. http://dx.doi.org/10.2307/1991130 